\title{
水害発生後の復旧期における 行政機関の対応に関する住民の意識
}

Residents’ Awareness for Recovery Activities of Administrative Agency

\author{
照本清峰 1 ・佐藤照子 2 ・福直輝旗 3 \\ Kiyomine TERUMOTO, Teruko SATO and Teruki FUKUZONO \\ 1正会員 博 (都科) 人と防災未来センター（ ₹ 651-0073神戸市中央区脇浜海岸通1-5-2) \\ 2 地理修 独立行政法人防災科学技術研究所（† 305-0006 つくば市天王台3-1） \\ 3正会員 独立行政法人防災科学技術研究所（干305-0006 つくば市天王台3-1）
}

\begin{abstract}
The purpose of this study is to examine residents' awareness for recovery activities. A questionnaire survey was administered to residents in the cities of Sanjo and Toyooka. These cities experienced devastating flood disaster in 2004. Our research question concerned the recovery activities of administrative agency and respondents' attribute. The results show that residents' satisfactions for recovery activities of administrative agency were low and the factor contributing to satisfaction with these activities was livelihood assistance for those affected.
\end{abstract}

Key Words : Degree of residents' satisfaction, Administrative Agency, Recovery activity, Awareness of residents, Questionnaire survey

\section{1. はじめに}

河川管理において水害リスクの軽減をはかるためには, 治水施設の整備等による物理的な被害軽減対策だけでな く，水害発生後の対応や住民の意識も考慮して総合的に 取り組むことが求められる. 水害発生後の対応において, 生命の危険性のある緊急期だけでなく, 緊急期を脱した 後の復興に向けての対応をとる時期は，被害を軽減する とともに復興をスムーズに進める上で重要である。本研 究ではこの期間を水害発生後の復旧期とし，復旧期にお ける行政機関の対応に関する住民の意識について分析す る.

馬越は，被災地域住民を対象とした意識調査をもとに 生活復興における不満の要因を明らかにしている1)。ま た群馬大学工学部防災研究グループ他では，平成16年新 潟・福島豪雨災害の被災地域を対象として，住民の水害 に対する行政要望について調査している2). しかし住民 の意識からタた復旧期における対応方策のあり方につい ては十分には検討されていない. 水害対応における復旧 期の課題に関する研究はこれまで本格的にはなされてこ なかった.

復旧期において, 行政機関の対応は被害を軽減するた めに重要な役割を果たす。そこで本研究では，行政機関 の対応に対する住民の評価を通じて，住民の満足度の観 点から課題を検討するとともに，住民の満足度を規定す
る要因について分析することを目的とする.

行政機関の実施する復旧期の対応としては，緊急的な 対応終了後に必要となる被災者への物資の供給から始ま り，公衆衛生に関わる対応，応急的な仮設住宅の確保等， 被災者の物理的, 精神的な支援まで多岐にわたる. 本研 究ではこれらの復旧期の対応項目を設定し，水害の被災 地域住民に対して実施した意識調査をもとに分析する.

\section{2. 調査の概要}

\section{(1) 調査対象地域の被害の概要}

2004年は台風の上陸件数が観測史上最多の10個を記 録し，それとも相まって例年と比較して水害の多い年で あった，その中でも，平成16年7月新潟・福島豪雨と台 風0423号による水害は特に大規模な被害をもたらした 3)4．各水害において，平成16年7月新潟・福島豪雨では 新潟県三条市，台風0423号では兵庫県豊岡市は最も甚 大な被害を受けた地域である。本研究ではこれらの2市 を対象にしている. 表-1に各自治体の被害の概要を示す.

表-1 調查対象地域の被害概要

\begin{tabular}{|r|r|r|r|r|r|r|}
\hline 自治体 & 発生日時 & 死者 & 全壊 & 半壊 & $\begin{array}{c}\text { 床上 } \\
\text { 浸水 }\end{array}$ & $\begin{array}{l}\text { 床下 } \\
\text { 浸水 }\end{array}$ \\
\hline 三条市 & 7月13日 & 9名 & 1 & 5172 & 315 & 1420 \\
\hline 豊岡市 & 10月20日 & 1名 & 394 & 3418 & 310 & 2394 \\
\hline
\end{tabular}




\section{(2) 調查方法}

調査対象は，被災した世帯とともに非被災世帯も比較 のために対象とするため，新潟県三条市，兵庫県豊岡市 の各自治体内を浸水区域と非浸水区域に分け，浸水区域 から500世帯，非浸水区域から500世帯を抽出した。調 查は郵送配布・郵送回収により行い，調查票は三条市に おいては 2005 年 2 月 14 日，豊岡市においては2005年2月 10 日に配布し，それぞれ3月7日に回収を打ち切った。 有効回答率は三条市 $34.4 \%(344 / 1000)$, 豊岡市 42.1\%(421/1000)であった。図-1に回答者の属性を示す.

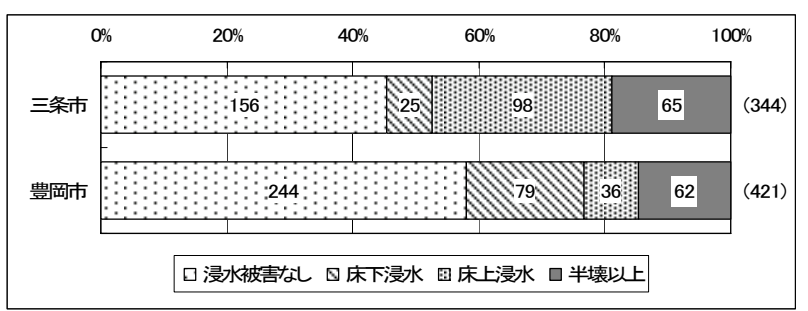

図-1 回答者の属性

\section{(3) 分析の内容}

分析は, (2)調查方法で示した住民に対する意識調査 結果をもとに，復旧期における行政機関の対応に関する 住民の評価を満足度の観点から行う．3．では，復旧期 における行政機関の対応に対する住民の満足度を把握す るために，各項目を集計するとともに，浸水被害区分別 の属性間の意識を比較し，分析結果から抽出される復旧 対応における課題について考察する４４で゙，復旧対 応の各項目によって表される因子構造について分析する とともに，各因子を用いて総合的な満足度に対する規定 要因を分析寸る．5．では，復旧対応の個別対応項目以 外にも満足度に与えている影響について検討するために, 回答者の属性とともに，関連すると考えられる意識項目 が総合的な満足度に与える影響について分析する.

\section{3．復旧期の対応に関する住民の意識}

\section{(1) 集計結果}

ここでは，水害発生後の復旧期における行政機関の対 応に対して住民の満足度の観点から分析する. 質問は, 水害発生後の復旧期における行政機関の対応に関する項 目に対して，「非常に不満」から「非常に満足」までの 5 件法で尋ねている，以下では，「非常に不満」を1点，

「非常に満足」を5点とし，便宜的に順序尺度を間隔尺 度と見なして分析する. 調査において設定した復旧期の 対応項目とともに，各自治体の浸水被害区分別の回答の 集計結果を表-2に示寸．また浸水被害区分間ごとの自治 体間の住民意識の違いをみるために，被害属性別（浸水 被害なし別，床下浸水別，床上浸水別，半壊以上別）に 一元配置分散分析を行った。表-3に分析結果を示す.

\section{(2) 考察}

表-2より，「浸水被害なし」の属性を含めて全体的に 中央值である3よりも低い平均值を示し，各項目とも満 足度は低い傾向にあることがわかる。 また被災程度が大 きくなるほど，満足度は低い傾向にある.

項目別にみると, 自治体別の各属性とも「(3)水害後 に各家庭からでる災害ごみの処理」がもっとも満足度が 高い結果であった。災害ごみは水害発生後の復旧期にお いては交通渋滞，衛生面の課題を引き起こすなど大きな 問題になる。 それにもかかわらず満足度が相対的に高 かった理由として, 他の項目と比較して行政機関の対応 の努力が目に見えていたことが理由として考えられる.

逆に満足度の低い項目としては，「被災住宅の被害認 定の方法」と「被災者への災害見舞金の支給内容」があ げられる．被災住宅の被害認定は各自治体によって様々 な方法がとられる，そのため，被災者にとって被害認定 の方法は不透明である場合も多く, 不公平感を生じさせ

表-2＼cjkstart復旧過程の対応に関する評価の集計結果

\begin{tabular}{|c|c|c|c|c|c|c|c|c|}
\hline \multirow[b]{2}{*}{ 項目 } & \multicolumn{4}{|c|}{ 三条市 } & \multicolumn{4}{|c|}{ 豊岡市 } \\
\hline & $\begin{array}{l}\text { 被害 } \\
\text { ‘ }\end{array}$ & $\begin{array}{l}\text { 床下 } \\
\text { 浸水 }\end{array}$ & 床上 & $\begin{array}{l}\text { 半壊 } \\
\text { 以上 }\end{array}$ & $\begin{array}{l}\text { 被害 } \\
\text { なし }\end{array}$ & $\begin{array}{l}\text { 床下 } \\
\text { 浸水 }\end{array}$ & $\begin{array}{l}\text { 床上 } \\
\text { 浸水 }\end{array}$ & $\begin{array}{l}\text { 半壊 } \\
\text { 以上 }\end{array}$ \\
\hline （1)被災者に対する生活復旧に必要な物資の供給 & 3.11 & 2.68 & 2.79 & 2.82 & 2.94 & 2.93 & 2.72 & 2.34 \\
\hline (2)被災者への支援施策に関する情報の提供 & 2.65 & 2.33 & 2.46 & 2.44 & 2.97 & 2.86 & 2.89 & 2.38 \\
\hline (3)水害後に各家庭からでる災害ごみの処理 & 3.15 & 3.21 & 3.10 & 3.10 & 3.18 & 3.03 & 3.19 & 3.10 \\
\hline (4)感染症を防ぐための衛生面の対応 & 3.10 & 3.13 & 2.92 & 2.77 & 2.94 & 2.79 & 2.44 & 2.64 \\
\hline (5)水害後に健康を害した被災者への医療面の対応 & 2.96 & 2.74 & 2.87 & 2.75 & 3.02 & 2.86 & 2.82 & 2.72 \\
\hline （6)被災者に対する心のケア & 2.92 & 2.75 & 2.74 & 2.57 & 2.96 & 2.86 & 2.67 & 2.57 \\
\hline (7)水害後に発生する犯罪に対する防犯体制 & 2.64 & 2.71 & 2.80 & 2.54 & 2.89 & 2.79 & 2.83 & 2.61 \\
\hline (8)被災住宅の被害認定の方法 & 2.43 & 2.38 & 2.68 & 2.21 & 2.69 & 2.61 & 2.72 & 2.71 \\
\hline (9)被災者の応急的な住宅確保のための支援策 & 2.82 & 2.83 & 2.85 & 2.60 & 2.85 & 2.95 & 2.60 & 2.69 \\
\hline （10)被災者への災害見舞金の支給内容 & 2.55 & 2.42 & 2.61 & 2.11 & 2.62 & 2.44 & 2.58 & 2.25 \\
\hline （11)被災者かららの復旧に関連する相談への対応体制 & 2.82 & 2.83 & 2.81 & 2.57 & 3.00 & 2.99 & 2.64 & 2.68 \\
\hline (12)被災者に対する行政職員の応対の態度 & 2.93 & 2.63 & 2.87 & 2.67 & 3.03 & 2.93 & 2.81 & 2.92 \\
\hline （13)被災者に対する支援施策の決定時期 & 2.61 & 2.48 & 2.65 & 2.36 & 2.83 & 2.84 & 2.61 & 2.57 \\
\hline (14)上記(1)～(13)の項目に関する総合的な対応 & 2.83 & 2.64 & 2.79 & 2.48 & 2.93 & 2.78 & 2.69 & 2.69 \\
\hline
\end{tabular}


表-3 浸水被害属性別の自治体間の検定結果

\begin{tabular}{|c|c|c|c|c|}
\hline 項目 & $\begin{array}{c}\text { 被害 } \\
\text { なし別 }\end{array}$ & $\begin{array}{c}\text { 床下 } \\
\text { 浸水別 }\end{array}$ & $\begin{array}{c}\text { 床上 } \\
\text { 浸水別 }\end{array}$ & $\begin{array}{r}\text { 半壊 } \\
\text { 以上別 }\end{array}$ \\
\hline (1)物資供給 & $\mathrm{ns}$ & $\mathrm{ns}$ & $\mathrm{ns}$ & * \\
\hline (2)情報提供 & $* *$ & $*$ & ns & ns \\
\hline (3)災害ゴミ処理 & $\mathrm{ns}$ & $\mathrm{ns}$ & ns & ns \\
\hline (4)衛生面対応 & $\mathrm{ns}$ & $\mathrm{ns}$ & * & $\mathrm{ns}$ \\
\hline (5)医療面対応 & $\mathrm{ns}$ & $\mathrm{ns}$ & ns & ns \\
\hline (6)心のケア & ns & $\mathrm{ns}$ & ns & ns \\
\hline (7)防犯体制 & $* *$ & $\mathrm{~ns}$ & $\mathrm{~ns}$ & ns \\
\hline 8)被害認定 & * & $\mathrm{ns}$ & ns & * \\
\hline (9)念急住宅確保 & ns & $\mathrm{ns}$ & $\mathrm{ns}$ & ns \\
\hline (10)見舞金支給 & ns & $\mathrm{ns}$ & ns & ns \\
\hline (11)相談対応 & * & $\mathrm{ns}$ & ns & ns \\
\hline (12)職員応対態度 & $\mathrm{ns}$ & $\mathrm{ns}$ & $\mathrm{ns}$ & ns \\
\hline (13)施策決定時期 & * & $\mathrm{ns}$ & ns & ns \\
\hline (14)総合的な対応 & ns & ns & ns & $\mathrm{ns}$ \\
\hline
\end{tabular}

ると考えられ，そのことが住民の満足度を下げている要 因の一つだと推察される．また「被災者一の災害見舞金 の支給内容」においては，被災者の被害額と比べた配分 額の少なさに起因していると推測される.

浸水被害属性別の意識を比較寸ると，表-3の分析結果 より，半壊以上別及び被害なし別の「(8) 被災住宅の被 害認定の方法」で統計的に有意な差がみられる。「被災 住宅の被害認定の方法」においては，豊岡市で相対的に 高い平均值であった．台風0423号発生後の2004年10月28 日に内閣府より「浸水等による住宅被害の認定につい て」の通知がなされた ${ }^{5}$ 。ここでは，以前よりも浸水被 害の実態に即した詳細な判定をする指針が示されている. これに基づき兵庫県では住宅被害認定のマニュアルを作 成し6)，豊岡市では兵庫県の作成した住宅被害認定のマ ニュアルをもとに調査している．このような詳細な調査 が豊岡市の半壊以上の被災者の満足度をあげた要因だと 考えられる，一方で三条市ではそれ以前の指針に基づい て被害認定を行っていた，被害認定の結果はその後の支 援内容に大きな差を生じさせる. 住宅の浸水被害は一見 したところ損傷のないような場合でも，衛生設備などは 使用できない場合もある，そのため，きめ細かい調査に 基づいた判定が求められる.

被害のあった属性に着目寸ると，「(1)被苂者に対す る生活復旧に必要な物資の供給」の半壊以上別及び 「(4) 感染症を防ぐための衛生面の対応」の床上浸水別 において統計的に有意な差がみられた。これはそれぞれ， 三条市と比較して豊岡市では浸水区域が広範囲であった ため，相対的に物資が行き渡らなかったことに起因して いると考えられる．また「(2) 被災者一の支援施策に関 する情報の提供」の床下浸水別においては, 豊岡市の方が 高い平均值を示す結果であった. これは, 豊岡市において は各戸別に希望者に対して防災行政無線が配布されており， 防災行政無線を介した情報提供に起因していると推測され る.

\section{4. 行政機関の復旧対応に関する住民意識の構造}

\section{(1) 因子分析結果}

次に，行政機関の復旧対応に対する住民の評価の関連 構造を把握するため，上記の各対応項目を用いて分析を 進める.

はじめに，復旧期の行政対応の評価に関する構成因子 を把握するため，(1)〜(13)の各項目（14は除く）をもと に，三条市，豊岡市別に探索的因子分析を行った. 分析 においては，主因子法，Promax回転を適用した7)。因 子数の決定に際しては, 各因子の意味の解釈可能性を考 慮した結果，三条市，豊岡市ともに同様の因子構造を示 し，3因子が抽出された．表-4(1)，表-4(2)に各自治体 の分析結果を示寸.

表-4(1)，表-4(2) より各自治体別の分析結果ともに, 第一因子は「被災者への生活再建支援の対応」，第二因 子は「被災者への生活復旧支援の対応」，第三因子は 「被災者への応急的な支援の対応」と解釈した。

表-4（1） 復旧対応に関寸る項目の因子分析結果 (三条市)

\begin{tabular}{rrrrr}
\hline & $\mathrm{F} 1$ & $\mathrm{~F} 2$ & $\mathrm{~F} 3$ & 共通性 \\
\hline 見舞金支給 & 0.749 & 0.007 & 0.075 & 0.623 \\
被害認定 & $\overline{0.635}$ & 0.130 & 0.047 & 0.527 \\
相談対応 & $\underline{0.593}$ & 0.200 & 0.185 & 0.660 \\
応急住宅確保 & $\underline{0.575}$ & 0.195 & 0.113 & 0.557 \\
施策決定時期 & $\underline{0.495}$ & 0.184 & 0.251 & 0.573 \\
職員応対態度 & $\overline{0.411}$ & 0.276 & 0.301 & 0.617 \\
医療面対応 & 0.088 & $\underline{0.771}$ & 0.085 & 0.730 \\
心のケア & 0.230 & $\underline{0.685}$ & -0.030 & 0.638 \\
衛生面対応 & 0.043 & $\underline{0.587}$ & 0.261 & 0.574 \\
災害ゴミ処理 & 0.032 & 0.462 & 0.381 & 0.529 \\
防犯体制 & 0.295 & $\underline{0.426}$ & 0.036 & 0.403 \\
情報提供 & 0.190 & 0.039 & 0.693 & 0.668 \\
物資供給 & 0.098 & 0.112 & 0.686 & 0.627 \\
\hline 累積寄与率 & 50.20 & 55.39 & 59.42 & - \\
\hline$\alpha$ 係数 & 0.889 & 0.845 & 0.807 & - \\
\hline
\end{tabular}

表-4（2）復旧対応に関する項目の因子分析結果(豊岡市)

\begin{tabular}{rrrrr}
\hline & F1 & F2 & F3 & 共通性 \\
\hline 見舞金支給 & 0.721 & 0.127 & 0.094 & 0.698 \\
被害認定 & $\underline{0.711}$ & 0.105 & 0.024 & 0.604 \\
相談対応 & $\underline{0.660}$ & 0.168 & 0.097 & 0.645 \\
応急住宅確保 & $\overline{0.610}$ & 0.163 & 0.163 & 0.623 \\
施策決定時期 & $\underline{0.608}$ & 0.149 & 0.086 & 0.539 \\
職員応対態度 & $\underline{0.530}$ & 0.281 & 0.120 & 0.595 \\
医療面対応 & 0.086 & 0.811 & 0.064 & 0.778 \\
心のケア & 0.115 & $\underline{0.686}$ & 0.071 & 0.607 \\
衛生面対応 & 0.198 & $\underline{0.661}$ & 0.062 & 0.645 \\
災害ゴミ処理 & 0.216 & $\underline{0.543}$ & 0.017 & 0.465 \\
防犯体制 & 0.212 & 0.334 & 0.169 & 0.324 \\
情報提供 & 0.049 & 0.041 & 0.902 & 0.883 \\
物資供給 & 0.231 & 0.127 & 0.579 & 0.598 \\
\hline 累積寄与率 & 51.02 & 56.79 & 61.57 & - \\
\hline$\alpha$ 係数 & 0.906 & 0.836 & 0.821 & - \\
\hline & & & & \\
\hline
\end{tabular}




\section{(2) 重回帰分析結果}

（1）で得られた因子分析結果をもとに，各項目の総合 的な対応の満足度に対する規定要因を検討寸るため, 因 子分析の結果得られた各因子得点を独立変数とし,

$「(14)$ 上記(1)～(13)の項目に関する総合的な対応」を従 属変数とした重回帰分析を各自治体別に行った. 分析結 果を表-5に示す.

表 -5 より, 決定係数は三条市 0.76 , 豊岡市 0.77 であり, 各自治体とも高い值であることがわかる．総合的な満足 度に対する規定要因は各自治体ともに同様の傾向を示し ている. 標準偏回帰係数は「被災者一の生活再建支援の 対応」が高い值であり，それと比較して相対的には「被 災者一の生活復旧支援の対応」，「被災者一の応急的な 支援の対応」は低い值であった。

表-5 重回帰分析結果

\begin{tabular}{r|cr}
\hline 項目 & \multicolumn{2}{|c}{ 標準偏回帰係数 $(\beta)$} \\
& 三条市 & 豊岡市 \\
\hline 被災者への生活再建支援の対応 & $0.53^{* *}$ & $0.59^{* *}$ \\
\hline 被災者への生活復旧支援の対応 & $0.25^{* *}$ & $0.25^{* *}$ \\
\hline 被災者への応急的な支援の対応 & $0.24^{* *}$ & $0.17^{* *}$ \\
\hline \hline 決定係数 $\left(\mathrm{R}^{2}\right)$ & $0.76^{* *}$ & $0.77^{* *}$ \\
\hline & & \\
\end{tabular}

\section{(3) 考察}

分析の結果得られた「被災者への応急的な支援の対 応」,「被災者への生活復旧支援の対応」，「被災者へ の生活再建支援の対応」の各因子は復旧初期段階からの 時間的な流れに対応して構成されている. その中で, 満 足度を向上させる観点からは生活再建支援の対応が重要 であることが示された. 生活再建は, とりあえずの生活 を行えるようになった状況から被災前の状況に戻してい く復興過程に進んでいく段階にあたる。この期間におい ては，被災者を自立させやすくする対応とともに被災者 に対する公平な対応も重要である.

また，「被災者への生活復旧支援の対応」，「被災者 への応急的な支援の対応」の標準偏回帰係数は低い值で はあるが，統計的に有意な值であり，これらの対応も重 要であることを示している.

\section{5．住民の満足度を規定する要因}

ここでは, 行政機関の復旧期の対応に関する住民の評 価について，3.とは別の観点から分析する. 行政機関 の対応に関する総合的な評価に対しては, 復旧期におけ る個別の対応項目だけでなく, 様々な要因が関連してい ると考えられる．そこで回答者の属性とともに関連する と考えられる意識も加え, 総合的な満足度に対する規定 要因を分析する.

\section{(1) 分析に用いる意識項目}

災害発生以前から地域の危険性を住民がよく知らされ ていたと考えるならば，災害発生後の諸々の不満感は低 減されると考えられ，それは行政機関の対応についても 同様だと考えられる．また，堤防施設などのハード対策 を十分に行っていたと考える住民の意識，緊急対応など のソフト対策を行政機関が事前に十分に行っていたと考 える住民の意識も復旧期の行政機関の対応の満足度に対 して影響を与えていると考えられる. そこで，これらに 関連する意識項目を加えて, 行政機関の復旧対応に対寸 る住民の満足度の規定要因を分析寸る.

行政機関からの情報提供に関する意識は，「水害が発 生する以前に, 行政から住民一, 地域の水害の危険性に 関する情報提供は十分に行われていた」といら質問内容 に対し，「全くそう思わない」から「非常にそう思う」 までの5件法で尋ねている。.また，堤防施設の整備に関 する意識は，「河川の堤防の強化にもっと費用をかけて いれば，昨年の水害をなくすことができただろう」とい う質問内容に対し，緊急対応体制の整備に関する意識は 「水害が発生する以前, 現在住んでいる地域の行政機関 は, 水害に備えて緊急対応のための準備を十分に行って いた」という質問内容に対し，それぞれ同様に5件法で 尋水ている，それぞれの意識項目をここでは，「情報取 得意識」,「堤防整備意識」, 「緊急対応体制整備意 識」と呼ぶことにする. 図-2(1)～2（3）に各意識項目の 自治体別集計結果を示寸.

図-2(1)より，各自治体の回答者ともに地域の危険性 に関する情報提供はあまりなされていなかったと考えら れている傾向にある. 図-2(2)より, 堤防の整備に対し てはさらに費用をかけていれば水害をなくすことができ たと考えられている傾向にある. また図-2(3)より，行 政機関の緊急対応体制については，あまり整備されてい なかったと考えられている傾向にあることがわかる.

\section{(2) 数量化 I 類分析結果}

次に，上記で示した「情報取得意識」「「堤防整備意 識」, 「緊急対応体制整備意識」とともに回答者の属性 を加えて, 行政機関の対応に対する満足度の規定要因を 分析する. 図-3に各項目と行政機関の対応に対する満足 度のクロス集計結果を示す。

分析は, 三条市，豊岡市の全サンプルを用いて，全項 目に関する「総合的な対応」の満足度を被説明変数とし， 「自治体」，「浸水被害」，「居住年数」，「性別」の 各属性と「情報取得意識」,「堤防整備意識」, 「緊急 対応体制整備意識」を説明変数とした数量化 I 類によっ て行った. 図-4に分析結果を示寸.

図-4より，最も大きいレンジをもつ項目は「緊急対応 体制整備意識」であることがわかる．また「情報取得意 識」も偏相関係数の值は高く, 関連性のあることを示し た.「堤防整備意識」もやや低い值ではあるが，関連性 


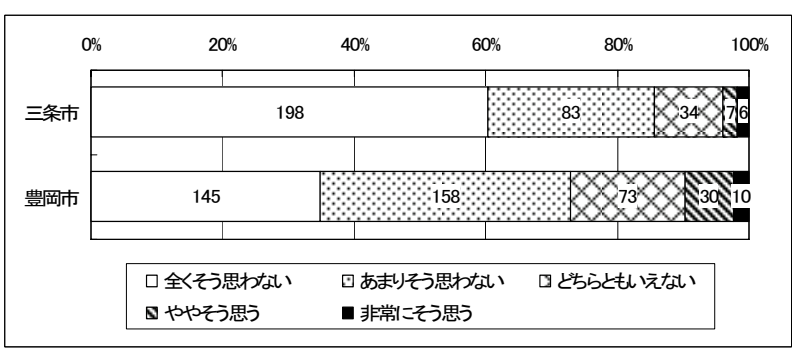

図-2（1） 情報取得に関する意識の集計結果

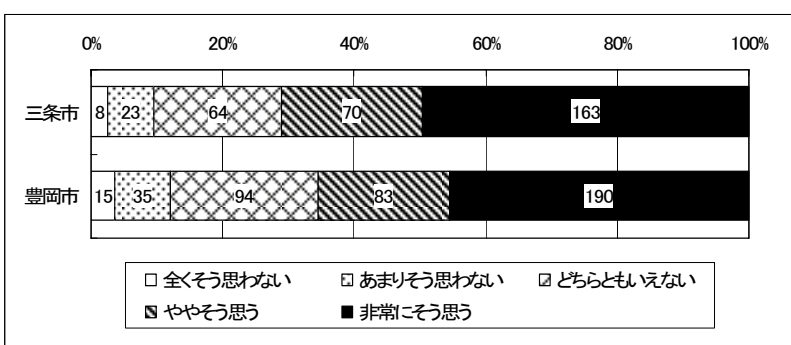

図-2（2）堤防整備に関する意識の集計結果

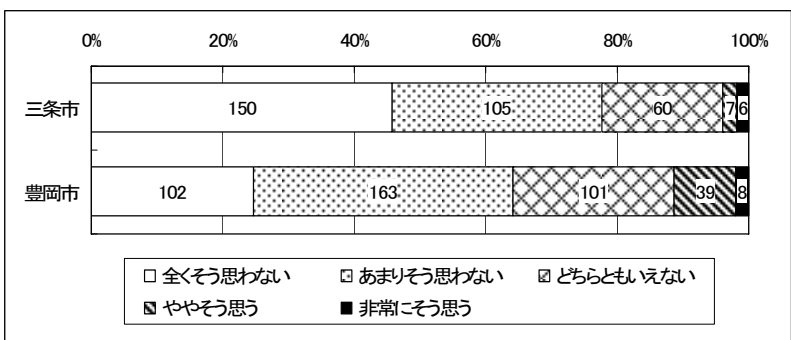

図-2（3）緊急対応の整備に関する意識の集計結果

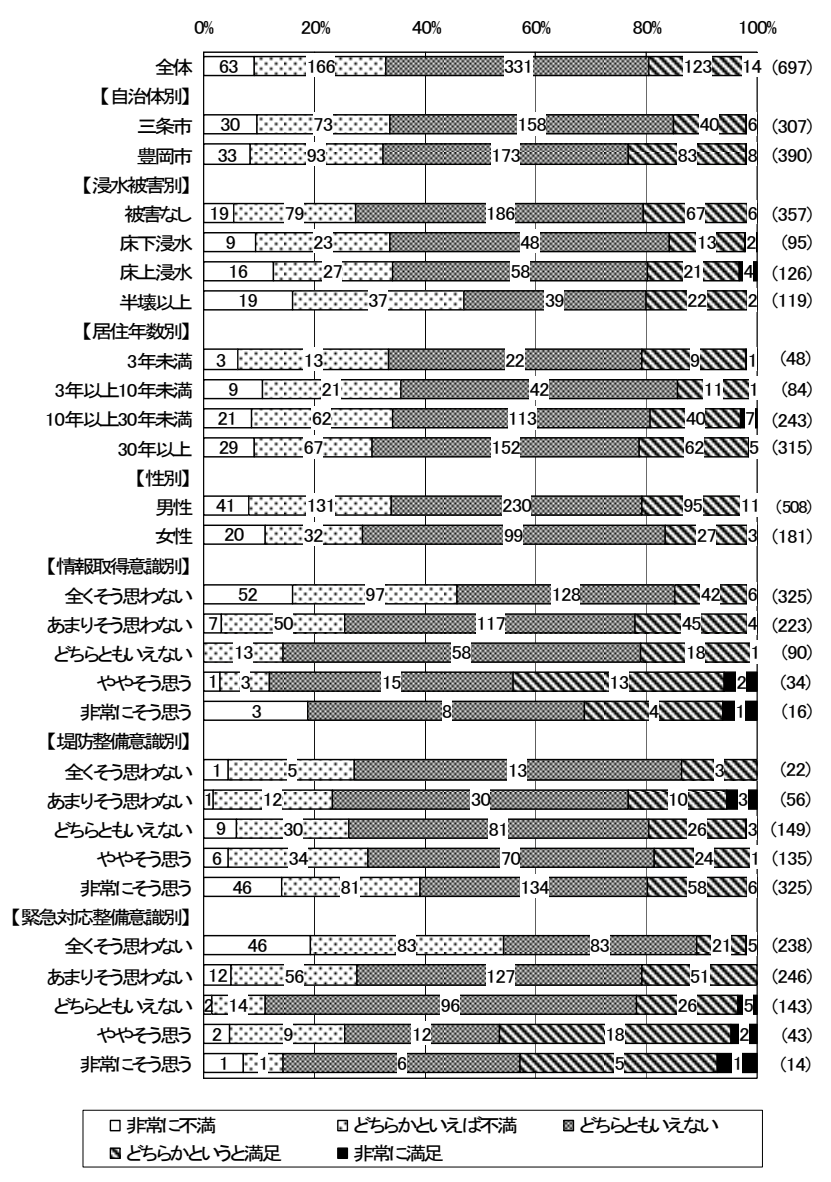

図-3 クロス集計結果
のあることがみられる.

逆に「自治体」，「浸水被害」，「性別」の各項目の 偏相関係数は低い值であった。 また「居住年数」の項目 のレンジも低い值であり, 回答者の属性よりも意識項目 が要因となっていることが示された.

\section{(3) 考察}

分析結果より，行政機関の復旧期の対応に関する住民 の評価に対して，「緊急対応体制整備意識」は規定要因 となっている。このことは，緊急対応体制を整備してお くことが重要であるとともに，緊急対応体制を整備して いるということを住民に知らせていくことも重要である ことを示している.ここでは緊急対応の整備に対する意 識項目から分析したが，ソフト対策全般について対策を 実施しているということを住民に知らせていくことは

(そのためには実際にしっかりと行っていることが必要 条件ではあるが），被害を軽減するとともに住民の満足 度を高めるためにも重要である。

また，「情報取得意識」も規定要因になっていること が示された．住民に対する情報提供として，水害に関す るハザードマップの住民への配布があげられる．2005 年4月の水防法改正により，中小河川を有する多くの市 町村自治体において住民に八ザードマップを配布するこ とが義務づけられるようになった．水害八ザードマップ の効果として，主に住民の避難行動をスムーズにするこ とや住民の防災意識を啓発することがあげられている8). しかしそれだけではなく，災害が発生した場合において 住民の不満感も低減することにつながることが分析結果 から示された. この理由として，事前に地域の危険性に ついて充分に認識していれば，被害に対する心理的なダ メージは低減されるということが推測される。すなわち, 水害発生前から被害の危険性のあることを認知していれ ば，いざ水害が発生した場合において，被災の物理的な 損傷の程度は同じでも心理的な喪失感は低減されること になり，ひいては行政機関に対する不満感も低減される ということである. 河川管理においては物理的な損傷だ けでなく住民の心理的な損傷も被害として捉え，心理的 な損傷を緩和するための事前のソフト的な対策の取り組 みも重要である.

\section{6. まとめ}

本研究では, 行政機関の実施した水害発生後の復旧期 における対応に対する住民の評価について分析してきた. その結果，以下のことが主に明らかとなった。

・復旧期の行政機関の対応についての満足度は全体的に 低い傾向にある

・復旧期の行政機関の対応について相対的に満足度の高 い項目は「水害後に各家庭からでる災害ごみの処理」 


\begin{tabular}{|r|r|r|r|r|r|}
\hline アイテム & カテゴリ & 度数 & スコア & \multirow{2}{*}{ レンジ } & 偏相関 \\
係数
\end{tabular}

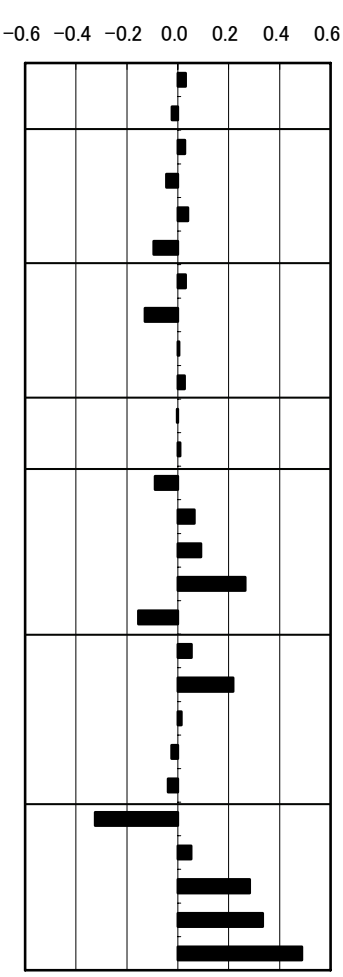

図-4 数量化 I 類分析結果

であり，逆に満足度の低い項目は自治体別・浸水被害 区分別に差がみられる

・復旧期の対応については，「被災者への応急的な支援 の対応」，「被災者一の生活復旧支援の対応」，「被 災者への生活再建支援の対応」の各因子があり, 総合 的な評価には「被災者への生活再建支援の対応」が大 きな規定要因となっている

・復旧期の行政機関の対応の満足度に対して, 行政機関 の緊急対応体制に関する意識，情報取得に関する意識 が規定要因となっており，逆に自治体，浸水被害等の 偏相関係数は低い值である

分析結果より，各項目とも行政機関の対応について住 民の満足度は低いことが示された. 行政機関の対応に関 する住民の満足度の低い理由として，そもそも災害に あったことにおけるあたりようのない不満を住民（特に 被災者）はもっており，その不満が行政機関に向けられ ていることに一因があると推察される. それとともに, 災害時における行政機関への過度の依存意識も背景にあ ると考えられる. 寸なわち，行政機関一の依存意識のた めに復旧に関する対応について多くのことを行政機関が 実施するべきだと考えるが，復旧期には自助の割合が高 いために, 行政機関の対応に対して満足度が高まらない ことが結果として表れていると推察される. そのため, 住民の自己責任意識を向上させていくことは重要な対策 の一つである．住民の自己責任意識を高めるために，災 害時に行政機関は多くのことに対応することは困難であ ることを説明することが重要である.
また行政機関としても，緊急対応体制を整備するとと もにそのような対策を講じていることを住民にも知らせ ていくこと，地域の危険性を住民に知らせていくこと等， 従来の治水施設整備に依存した対策だけでなく, 総合的 に水害対策に取り組むことの重要性が分析結果より示さ れた。これらの対策によって行政機関への依存意識も低 くなり，ひいては行政機関の対応についての不満も減少 するとともに，心理的な喪失感も含めた総合的な被害は 軽減すると考えられる.

\section{参考文献}

1）馬越直子 : 生活復興に対する被災者の評価と対策のあり方 に関する研究，博士論文（東京都立大学）, 2003 .

2) 群馬大学工学部方災研究グループ他 : 平成 16 年 7 月新潟 豪雨災害に関寸る実態調査調査報告書, 2004 .

3）大熊孝 : 2004 (平成 16) 年 7 月 13 日新潟水害の速報,土 木学会誌,Vol.89, No.9, pp.45-48, 2004.9 .

4）辻本哲郎，井上和也：台風 21２3 号による豪雨災害緊急 調査（速報）,士木学会誌,Vol.89, No.12, pp.23-29, 2004.12.

5）内閣府通達 : 府政治防災第 842 号, 2004.10.28.

6) 浸水等による住宅被害の認定に係る内閣府通知（平成 16 年 10 月 28 日）の解釈について，兵庫県企画管理部防災局， 2004.11.4.

7）柳井晴夫 : 多変量デー夕解析法，朝倉書店，1994.

8）片田敏孝, 巟玉真, 佐伯博人 : 洪水ハザードマップの住民 認知とその促進策に関する研究, 水工学論文集, No.48, pp.433-438, 2004.

(2005. 9. 30受付) 